\title{
Popular Protest in Portugal: The Douro Region in First Half of Nineteenth Century
}

\section{Célia Taborda Silva}

Ph.D in Contemporary History University Lusófona of Porto

\section{Doi:10.5901/ajis.2013.v2n8p91}

\begin{abstract}
In the 19th century in the Douro region (where port wine was produced) there were still social protest which were considered to be pre-modern, that is, they had typical features of the protests that occurred before the 18th century, such as banditry or millenary movements. These movements didn't have any organized structures such as political parties or trade unions and took place spontaneously and sporadically, having emerged as a reaction to the changes introduced by the new liberal politics and capitalist society.
\end{abstract}

Keywords: Douro, social protest, pre-modern, liberalism

\section{Introduction}

The Douro region situated in the North of Portugal is known for its famous Porto wine and because it became a world heritage in 2001. This region became a limited and regulated one in the $18^{\text {th }}$ century. The demarcated zone established geographically along the Valley of the Douro River and some of its tributaries of the two banks, over $100 \mathrm{~km}$. This area is subdivided into three subregions: Baixo Corgo, Cima Corgo Douro Superior (Pereira, 1991), and wavering between the Valley and the mountain, giving it a natural individuality that clearly distinguishes this from neighbouring territories of Trás-0S-Montes and Beira with that limited, and that Portuguese geographers as well showed ${ }^{1}$. The idea of protecting this territory was born in the kingdom of King José I, when his Minister, Sebastião José de Carvalho e Melo, known as Marquês de Pombal had the idea of demarcating this territory, which for a long time had dedicated itself to the growth of vineyards ${ }^{2}$ and that nowadays still produces a wine whose quality is recognized all over the world.

The very first limitation of this region took place in 1756 , due to the need of preserving a wine which since the $16^{\text {th }}$ century had become a great source of wealth for our country and which was being adulterated by fraudulent practices and therefore losing its quality. As a consequence of this loss of quality one of its major clients- the English- no longer wanted to purchase this wine. This led to a commercial crisis and consequently to the poverty of a region whose source of wealth was the growth of vineyards.

The conditions for the State to interfere in this sector were therefore created with the appearance of new commercial companies that followed the pattern of the economic policy which had been put into practice since 1753. So, under the order dated $10^{\text {th }}$ September 1756, Marquês de Pombal imposed the limitation of the region and created a dominating State company known as Companhia geral da Agricultura das vinhas do Alto Douro. This company controlled the whole process, from the production to the sale of the Douro wine (Pereira, 2010, p.12). This is how the oldest region in the world with limitations and rules was born ${ }^{3}$.

The wine and the vineyard growth ended up being what really defines and distinguishes the Douro region. This region in the Portuguese territory can be considered "atypical", by the extent of commercial wine production relations in it introduced. We could admit that this greater openness to the outside might have favored a more positive reaction to

\footnotetext{
${ }^{1}$ Like Amorim Girão (1930); Orlando Ribeiro (1987); Vergílio Taborda (1933).

${ }^{2}$ Since pre-history there have been signals which show that vineyards were grown in that region. Vide Cortez, R. (1951). As escavações arqueológicas do "Castellum" da Fonte do Milho. Porto: Instituto Vinho do Porto. In the Roman time the vineyards were grown on the Douro hills. Vide Ameida, C.A.B. (1993). O aro arqueológico de Carlão-Alijó. O cultivo da vinha na época romana. Estudos Transmontanos. Vila Real. 5.

${ }^{3}$ Although the Portuguese are pleased to think this was the first demarcated region in the world, in fact it wasn't. There was one in Tuscany in 1716 and another one in Hungary in 1737. However, the Douro region was the first to be limited in this way.
} 
liberalism and capitalism by part of this rural area, but, as we shall see, did not happen and was reason for popular protests. So it is easy to understand that the growth and development of the territory happened as the vineyard growth took place and that this region can't be analyzed isolated from the Douro wine.

In fact this region is the result of the continuous men's effort, that turned Douro into a unique region with one of the most impressive built landscapes.

In the $19^{\text {th }}$ century the Douro region had to adapt itself to the political, economic and social changes imposed by Liberalism (Cardoso, 2007) namely the end of the protectionism and the liberalization of the vineyard sector which brought about big economic changes in the region that led to political and social contend.

The Liberal Revolution happened in Portugal in 1820, but it was only completely consolidated in 1834 (Bonifácio, 2002). However there were still fights between the ones who had the absolute power (that dominated for two centuries) and the ones who stood for the liberal ideology. This fights were particulary intenses in Douro (Silva, 2007). The political rivalry happened mainly between the sons of King João VI. The older, Pedro, was liberal and defended the constitutional monarchy. The younger, Miguel, was in favour of the absolute monarchy. After their father's death these disagreements led the country to a fratricide Civil War. This Civil War ended with the victory of $D$. Pedro and the triumph of Liberalism in 1834 .

The settlement of Liberalism, however, was characterized by conflicts due to the economic, social, mental and even religious underdevelopment in which the country lived. The changes made to develop the country affected the structures of the ruling power and people's mentality, thus creating reactions which led to various popular protests in the Douro region.

In this article we will analyze the most "primitive" of the popular protest, those who happen in transition of the absolutism to liberalism. Protests, impossible to imagine nowadays, but a reality in Douro by that time.

It was based on the documents which can be found in the Central Archive of our country, known as Torre do Tombo, showing the letter exchange between the Civil Governors of the districts of Bragança, Vila Real, Viseu and Guarda and the Minister of the Kingdom that we tried to understand how the Douro region reacted to the implementation of liberalism and capitalism, searching in those documents for situations in which the social order was affected.

In this article we point out some of those pre-modern social protests that occurred in the Douro region in the $1^{\text {st }}$ half of the $19^{\text {th }}$ century and emphasize the importance of the studies of two English Historians, Hobsbawm and Thompson, who, with their innovative concepts, helped to classify and understand the type of "primitive" or "archaic" protests that happened by that time in a liberal society, a supposedly modern one.

\section{The problematic of the "primitive" popular protest}

The studies of Eric Hobsbawm and Edward Thompson were very important for understand pre-modern popular protests. With their books "Primitive Rebels" written by Hobsbawm and "The Moral Economy of the English Crowd in the eighteenth century", written by Thompson, the two historians became extremely important as far as the social historiography is concerned.

In his book "Primitive Rebels" Hobsbawm studied the peasantry, a social group that in spite of having been the silent leading figure of the European History, had been despised by the historians as elements of a past that was disappearing as times evolved. He also studied the pre-modern rebellions in contemporary times. That means that he tried to call people's attention to a certain type of social protest expressed in an unconventional way that was beyond the organizational structure of the political parties or trade unions, no longer supposed to exist in that period of History, after the Industrial Revolution. Those types of social protests still occurred frequently and this fact led the author to classify them as "primitive" or "archaic" ways of social agitation.

"The Primitive Rebels" aims to show the types of protest that were the result of the confrontations between the capitalist system and the traditional social organization. The social movements occurred due to the attempt of the people to adapt themselves or due to their inability to adapt to the new reality. Among those movements Hobsbawm studied the Social Bandit, revolutionary peasantry movements of the Millenarianism kind and rural secret societies. (Hobsbawm, 1978, p. 11)

This pre-modern agitation wasn't either often analyzed, or recognized as having any kind of importance, because it can't be included in the patterns of the modern social movements, the ones that took place in the last part of the $18^{\text {th }}$ century. This kind of agitation could more likely be included in the occasional phenomena that happened in the Middle Age. But the truth is that it was a reality in the $19^{\text {th }}$ and $20^{\text {th }}$ centuries, happening at the same time as the modern protest movements. When the historians valued this agitation, what rarely happened, they understood it as a forerunner of the 
modern worker movement. What Hobsbawm actually did was to understand the function of this type of movement in the process of modern protests.

The ones who took part in those primitive protests hadn't found a specific language to express their aims about the world yet and therefore their actions were considered pre-political. Their culture was mainly oral because they were illiterate in the majority (Hobsbawm, 1978, p. 12).

These people, who weren't born or raised in a modern or capitalist world, had to face the production relationships and the capitalism logic that interfered with their traditional world. The confrontation of these two realities caused conflicts, expressed in pre-modern terms and with a pre-political language.

Douro in the confrontation with the liberalism and capitalist economy also generated this kind of pre-modern movements, with popular protests similar to those identified by Hobsbawm as banditry and millenarian movements.

When the peasants gained a major importance they started attracting the attention of the investigators of the anthropology area, rural sociology and social history. Hobsbawm had a crucial role in the spreading of these studies on peasants, since he was part of the editorial group of the Journal of Peasant Studies, and contributed with the article "The Peasants and Politics" in the first number of this Journal.

Edward Thompson in "The Moral Economy of the English crowd in the eighteenth century" (1979, p. 62-134) analyzed the type of the social classes fight in the pre-industrial society, although he didn't study all the classes, only the crowd that took part in the market actions. As the author refers, the aim of his analysis was "the mentality or, as he preferred to name it, the political culture, the expectations, the traditions and the superstitions of the working class who frequently took part in the market actions; and the relationships, sometimes negotiations, between the crowd and the State that were classified as riots" (1995, p. 295-296).

It was in this context that Thompson got interested in the food riots that occurred in England in the $18^{\text {th }}$ century (1995, p. 296) although he didn't study them in a very detailed way, since they just interested Thompson as examples of their "moral economy".

The food riot in the $18^{\text {th }}$ century in England was a very complex way of direct popular action, which was disciplined and had clear aims (1978, p. 65). It is obvious that the quick rise of prices, incorrect attitudes of the traders or hunger were reasons for the food riots to happen $(1979$, p. 65-66). Thompson's view contrasts with the one of many historians, who explained these riots due to "economical reasons"4, Thompson doesn't agree with this economic point of view, because in almost all the crowd actions in the $18^{\text {th }}$ century it is possible to notice some legitimating reason $(1995$, p. 65), that is, men and women who took part in these riots believed they were defending right and traditional customs.

Thompson's method consisted in rebuilding a paternalistic model of the food trading, in which there were institutional and protective measures and other exceptional ones in times of scarcity. To understand the actions of a specific crowd it is necessary to pay attention to certain markets and commercial practices. But to understand the "political" space in which the crowd could act and negotiate with the authorities it is necessary to make a more detailed analysis between both. In this way we can't apply the conclusions of the "market economy" to other peasantry markets (1995, p. 296).

Douro region is an example of this, because there were a lot of economic crisis, some really critical has occurred in 1837, 1839, 1849, 1852 (Silva, 2007). In this periods the people have hungry, sometimes even starving, and they claim for governmental help but didn't made riots, because the "moral economy" wasn't broken. As Thompson said is necessary more than hunger to a group, a community or a social class response with a riot to a crisis (1995, p. 298).

Hobsbawm and Thompson work gave rise to a series of critical and pertinent historical literature (Molina, 1996; Alier, 1988; Mintz, 1982; Snell, 1985; Scott, 1976)), in spite of this they gave an important contribute to the social history, mainly to the historiography of social movements. In fact Primitive Rebels and Moral Economy introduced innovative concepts and solved a concept gap for social protests which were difficult to classify.

\section{The pre-modern popular protest that occurred in the Douro region.}

What we concluded on studying the Douro region was that in the middle of the $19^{\text {th }}$ century not only in this region but throughout the country there were social protests that couldn't be classified as typical conflicts of the $19^{\text {th }}$ century. As Hobsbawm had noticed in his studies about Spain and Latin America, also in Portugal there were "primitive" or "archaic"

${ }^{4}$ This is the view of the French Historians who since Labrousse reinforced the association between the social agitation and the food riots. Labrousse, E.(1993). Esquisse du mouvements des prix et des revenues en France au XVIII siècle. Paris: Dalloz, 2 vols. 
ways of social agitation that could be included within his concepts of "primitive rebellion": banditry and millenarian movements.

The food riots became more frequent when the moral, pre-modern economy clashed with the new economy of the free market that was introduced by Liberalism, threatening the traditional regulation of the market, aiming only at the profit and not paying attention to the needs of the population. In Douro the riot that we will describe also followed the same dynamic of the riots studied by Thompson, in which it was much more than hunger what motivated them. It was necessary to break certain rules of the market regulation, based on customs and "paternalistic" traditions for the people to start a revolt.

In the first part of the $19^{\text {th }}$ century in Douro in a time when Liberalism was gaining more importance, there were a great number of collective action, but not all generated violence or revolt. As Jean Nicolas (1984, p. 18) states, the contesting phenomenon must be seen in a group in which the violence is just one of its components.

\subsection{The banditry}

The first way of pre-modern agitation that occurred widely in Douro in the first half of the $19^{\text {th }}$ century was banditry.

The banditry and the riots reflect a "primitive" way of social contest, precisely in a moment of social organization, a turning point from an Absolutist to a Liberal model.

The banditry happened most frequently in Douro in the first half of the $19^{\text {th }}$ century. This region which was far from the sea, difficult to access and a stage of constant political fights was perfect as a hiding-place and quick escape for the ones who, with a "noble" or "vile" reason had decided to live outside the law.

We didn't find much information about the Douro bandits. Only some of their names, nicknames, origin, place where they acted and were captured (Silva, 2007). Even so we gathered enough information to conclude that the bandits were people who belonged to the rural community, who dedicated themselves mainly to agriculture, although some of them were cobblers, blacksmiths and became bandits as a way of survival ${ }^{5}$. They appear with much intensity in periods of economic crisis related to production or commercialization of wine, between 1834-1855 we count in Douro 21 conflicts of bandits (Silva, 2007, p. 261) . But there were others, yet just a few, that became bandits because they faced injustice or were chased and acted that way to resist, like "José do Telhado", a bandit who stole in the Douro (Silva, 2007, p.9496). These are the so called "noble" bandits (Hobsbawm, 1976, p. 44-65) totally different from the simple robber. Although for the authorities they were all the same - out-of-law men - in social terms there was a big difference. The social bandits stayed within the peasant society and were considered by their peers to be heroes who promoted the justice. That is why they were helped and supported. The actions of those bandits were acceptable within their values of behavior: they stole the rich to help the poor and they killed to honour themselves or any relative. It is this relationship between the peasant and the rebel that gives meaning to the social banditry and that differentiates these bandits from the "road thieves" (Hobsbawm, 1976, p. 10). The social bandit didn't steal anything from the peasants. Just from the rich people. For that reason his popularity was only visible inside his regional social group. A man could be a social bandit in the place where he lived and a simple thief outside it (Hobsbawm, 1976, p.10). This pre-political phenomenon disappeared gradually with the modernization, because it was supported by societies based on agriculture, fighting for the maintenance of traditional values (Hobsbawm, 1976, p. 24).

In Douro we acknowledged what Hobsbawm had stated in his book "Bandits" (1976), that the banditry was a typically rural phenomenon, mainly in rocky places with a difficult access. Besides that it was essentially a way of individual rebellion of a minority inside the peasant society (E. Inman Fox, p. 19). Historically it took place in times of political instability, economical crisis or between phases of evolution of the social organization, for example in the transition to the Agrarian Capitalism. Moreover, as banditry was a pre-political phenomenon, it lasted only until the individuals gained a political awareness or acquired more efficient ways of social agitation (Hobsbawm, 1978, p. 31).

Therefore the banditry in Douro is seen as a way of "primitive rebellion", without any ideology or plans for a new society. Because of that it disappeared as a social phenomenon in the second half of the century.

\subsection{Millenarism}

Another type of social movement considered to be "primitive" was the Millenarianism, a messianic movement in which a

\footnotetext{
${ }^{5}$ Archive National Torre Tombo, A. S.E (Arquivo Secretarias de Estado), Ministério do Reino. Maço 2107.
} 
character gives himself or the ones around him supernatural or at least exceptional powers and appears preaching the arrival of a new world (Queiroz, 1985, p. 59).

In Douro there was a Millenarian movement that can be integrated in the messianic European movements. It took place in Granja do Tedo, a small village situated on the left bank of river Douro.

There were numerous messianic movements throughout History. But, as Maria Isaura Pereira de Queiroz states, these movements had identical characteristics: a Messiah announces the arrival of a new world (1965, p. 59), as we mentioned before.

What happened between 1837 and 1840 in Granja do Tedo was clearly a phenomenon of a messianic type, whose causes may derive from the change in the balance of the peasants' life. The same happened with the community of Davide Lazzaretti, where the Messiah from Monte Amiata (southeast Tuscany) appeared, around 1870, in a particularly difficult political moment for the Italian reunion. This area faced bad crops and an industrial crisis, starting to suffer the effects of the penetration of the capitalist economy (1965, p. 100-101). The Douro movement also took place in a time of political, economic and social transition, with the settlement of Liberalism 6 .

In Granja do Tedo the new religious movement was founded by Maria das Neves Custódio, the daughter of José Custódio, a local teacher. Influenced by a book that her brother had brought from the capital city- Lisbon- she started to preach her messianic gifts that had been detected during her childhood by a neighbourhood healer. As a Messiah, she had been sent by a Divinity to bring the victory of Good over Evil or to correct the world's imperfections allowing the coming of the Earth Paradise.

Due to her personal gift and charisma, she became a religious and social leader and because of her characteristics she placed herself above the existing hierarchies, subverting or disallowing them ${ }^{7}$. The aim was to moralize and sanctify the population as far as political, economic and social aspects are concerned, thus revealing the divine intention by means of special rituals.

Her religious ceremonies had festive characteristics. They were animated with music and dances and the members who attended them wore flowers as if they were already in the kingdom of perfection.

In her rituals there was a reversal of the traditional references, a subversion of the social hierarchies, an allowed critics as the one which happened at Carnival, a time when, for a few days people lived in an upside down world, creating their own imaginative figures (Bercé, 1994, p. 75). In this movement there was also music, dance and extravagance: Even the most solemn rituals such as the mass, the sacraments and prays that they kept were adapted. In the prays, such as in the Lord's Prayer, Holy Mary or Credo the words were replaced by others similar to popular prays. In litanies the name of saints were replaced by names of plants. In the mass the listeners didn't face the speaker and the communion wafer was replaced by orange wedges.

The standard changes established by the prophetess also affected the personal and familiar life of her followers, for example, as far as new marriages were concerned. She annulled her own marriage and got married again with her uncle. Besides that women were encouraged to change their sexual status by dressing as men.

"Maria Coroada's" preaches were part of the practices of this movement. They were characterized by a social criticism, a radical one towards the dominating social classes, namely towards the monarchy. The modern influences of the sect were probably brought by her brother from the city, where radical theories circulated among the literate ones. The historian Fátima Melo Ferreira believes that maybe there was an inspiration in the radical Lisbon "September clubs" to organize the political beliefs of this movement (2002, p. 53).

These mysterious ceremonies with a totally pagan appearance led this sect to be accused of immoral practices and nudism and consequently chased by the authorities (Silva, 2007, p. 212).

This movement is supposed to have appeared as a reaction to the falling of a known world, to the emptiness left by the liberal capitalism when it destroyed the ancient traditions without replacing them by new ones. The disorganization that followed the settling of Liberalism wasn't counterbalanced by the imposition of a new order and organization. Underlying this movement is the need of a reorganization of the peasants according to a familiar system reinforced by a religious foundation, similarly to what happened with the "Lazzaretists" (Queiroz, 1965, p. 120).

\footnotetext{
${ }^{6}$ According to Hobsbawm, "the start of modern capitalism in a peasant society, generally as liberal or Jacobin reorganizations (the introduction of a free agrarian market, the secularization of the Church properties, the equivalents of the closing movement and restructuring of common lands and forest laws, etc) always had apocalyptical effects over that society." Hobsbawm, E. (1978). Primitive Rebels. Rio de Janeiro: Zahar Editors, p. 73.

${ }^{7}$ This happened with all the ones who considered themselves to be "Messiahs". Queiroz, M. I. P. (1965). O messianismo no Brasil e no mundo. São Paulo: Dominus Editora, p.5.
} 


\subsection{Food Riots}

According to Thompson's line of thought, the lack of cereals could lead to hunger and to the subversiveness of the market relationships ending in riots. In Douro we can find riots similar to the ones described by the author. The rise of prices of the food items usually caused food riots ${ }^{8}$. The historians of social themes classified them as "pre-industrial movements", even if they didn't achieve the highest grade of conflict: the revolt.

The hunger that affected the Douro region in 1836 wasn't caused by the vineyard crisis. This time it was due to the scarcity of cereals, which led the sellers to rise the price of bread, as it was written on the Ecco newspaper on $7^{\text {th }}$ June, in the regions correspondence. This price rise led to popular manifestations in Mesão Frio.

The inhabitants of Oliveira, in Mesão Frio, demanded a meeting with the mayor to expose the hoarding of cereals by two or three sellers, that detained the cereals' monopoly and then rose the price. The people felt they were being robbed, since the sellers bought the cereals in Spain for a much lower price than the one they sold them in Portugal 9 .

Even more than the shortage what led the inhabitants of the village to organize a manifestation in front of the town council was the traders' attitude of subverting the market rules in hard times. The town council scheduled a meeting which was attended by almost all the inhabitants of the parish. They were accompanied by the parish commissioner, so as to avoid any conflicts. They arrived at Mesão Frio "orderly and quietly". However, they didn't meet all the members of the town council, but only the President, who was the county administrator's brother, someone whom the inhabitants didn't like. Although the people arrived orderly the president interpreted the arrival of such a crowd as a riot. When the people realized what the president thought about their gathering they started insulting the bread traders. The Administrator decided to call a military escort, so the people "went away quietly, yet angry about such unfairness." According to the journalist the Administrator reported what had happened to the Civil governor as a sedition ${ }^{10}$. Although the people only manifested against speculation in the price of grain, the rupture of what Thompson calls the "moral economy", derived of the new political economy of the free market of cereals. In times of extremely high prices and scarcity the crowd could direct action to impose a protective control of the market and the regulation of prices, claiming sometimes the legitimacy that derived from the paternalistic model (Thompson, 1995, p. 296).

Many times the popular reactions were reduced to small manifestations of hostility towards the landowners, hoarders or the authorities, as it happened in the food riot of Mesão Frio, in an attempt to restore the market regulation rules that existed in the quiet times, related to traditions and culture.

\section{Conclusion}

These pre-modern social movements reveal a reaction or inability to adapt to the new liberal order.

The fact that these rebellion phenomena are considered "primitive" or "archaic" doesn't mean that they appeared in communities that existed before the $19^{\text {th }}$ century. On the contrary, these type of protests arose from the confrontation between the capitalist system and the traditional social organization. What led Hobsbawm to classify them as "primitive" is the fact that they were organized by social groups who valued the family ties or community solidarity (Hobsbawm, 1978, p.13), as it happened among our bandits who were able to subsist for a long time only that way. In the Douro region this solidarity was also visible in terms of territory.

Although the banditry wasn't a typical popular protest, it had to be considered as a social phenomenon. In fact, although it was marginal in Douro region, it had its importance, as a collective action of a group of individuals who defied the established order, in an attempt to perpetuate the past, since their major difficulty was adapting to the new liberal and capitalist world. Therefore their acting is confined to the ending of Absolutism and transition to Liberalism.

As it happened with most of this phenomena in the countries analyzed by Hobsbawm, also in Douro, they didn't originate modern social movements, politically organized. For that reason they were classified as pre-political and reformist and not revolutionary (Hobsbawm, 1978, p. 12).

Undoubtedly the bandits' movements that we found fall into the category of the most primitive way of social protest.

\footnotetext{
8 In Spain there were various riots between 1895 and 1905. Arrieiro, Maria Luz (1984). The food riots in Spain, 1895-1905. Social History Studies , 30, 193-250.

9 " what this county is suffering because of two or three monopolists of that village that buy the bread at a price in Spain and sell it at a much higher one here in Douro." Ecco, 7th June 1836.
}

10 Ecco, 7th June 1836 
As Douro and all Portugal walked towards a political stability, these movements disappeared. Besides that, they were common to all the countries which were developing and for that reason they could still be found in Latin America in the $20^{\text {th }}$ century.

One of the reasons mentioned to differentiate the traditional ways of protest from the "modern" ones is that the former aren't against the basis of the established social order and contribute to maintain and reinforce the traditional and paternalistic practices, as it is referred by Thompson. In Douro when the liberalization of wine economy were introduce in the region with the liberalism the popular protests growing, because certain market regulation rules based on traditions were broken.

The popular protests were intense at the stage of introduction of liberalism (1834-1855) because they were a reaction to the new economic model which left the production and trade in the region exposed to the liberalization of markets. The end of protectionism in the Douro was marked by intense economic crises and consequently by riots.

However these ways of collective action were labelled as "traditional", or "pre-industrial", seeming a remaining of the past, they show in the first half of the $19^{\text {th }}$ century a clear importance of the popular within the social protest. At the same time the economic, political and social changes led to new ideas and experiences that would affect the society in an intense and permanent way, changing the features and ways of conflict. The progressive political reforms, the rising of capitalism and the modernization of the country due to industrialization, although weak and late, determined the gradual disappearance of the old forms of protest, since the persistence of customs and rights of the past didn't make sense in a world which was constantly changing. The local, spontaneous, sporadic and non-political manifestations were replaced by modern protests with national ideologies. It is yet obvious that this change from the old to the new wasn't that simple. It had different features according to each region. The transition from the traditional to the contemporary society took place at least throughout the whole $19^{\text {th }}$ century.

\section{References}

Alier, J.M.(1988). Crítica de la interpretación del anarquismo como «Rebeldia Primitiva». In Sevilla de Guzmán, E.; Heisel,K (Ed.) Anarquismo y movimiento jornalero en Andalucía. Córdoba: Ediciones de la Posada.

Arriero, M. L. (1984). Los motines de subsistencias en España, 1895-1905. Estudios de Historia Social. 30, 193-250.

Bercé, Y.M. (1994). Fête et revolte. Des mentalités populaires du XVle au XVIIIle siècle. Paris: Hachette.

Bonifácio, M.F. (2002). O século XIX português. Lisboa: Instituto de Ciências Sociais da Universidade de Lisboa, 2002.

Burke, P. (1990). La revolucion historiografica francesa. La escuela de los Annales: 1929-1989. Barcelona: Gedisa.

Cardoso, A.M. (2007). A revolução liberal em Trás-os-Montes (1820-1834). O povo e as elites. Porto: Afrontamento.

Ferreira, M.F.M. (2002). Rebeldes e Insubmissos. Resistências Populares ao Liberalismo (1834-1844). Porto: Afrontamento.

Ferreira, M.F.M. (1983). Mudança política. Religião e cultura popular: 0 «cisma» da Granja do Tedo. Ler História. Lisboa. 2 (1983) 4160.

Girão, A. (1930). Esboço de uma carta regional de Portugal. Coimbra.

Hobsbawm, E. (1976). Bandidos. Barcelona: Ariel. The first English version is 1969.

Hobsbawm, E. (1978). Rebeldes Primitivos. $2^{a}$ ed. Rio de Janeiro: Zahar Editores. The first English version is 1959.

Labrousse, E. (1933). Esquisse du mouvements des prix et des revenues en France au XVIII siècle. Paris: Dalloz, 2 vols.

Ladurie, E. Le Roy (1979). Le Carnaval de Romans. Paris: Galimard.

Mintz, J. (1982). The anarchists of Casas Viejas. Chicago: The University of Chicago Press, 1982.

Molina, M. G. (1996). Los mitos de la modernidad y la protesta campesina. A propósito de Rebeldes Primitivos de Eric J. Hobsbawm. História Social. Valencia. 25.

Nicolas, J. (1984). Un chantier toujours neuf. In Mouvements Populaires et Conscience Sociale, XVI-XIX siècles. Paris: Maloine.

Pereira, G.M. (1991). - O Douro e o vinho do Porto. De Pombal a João Franco. Porto: Afrontamento.

Pereira, G.M. (2010). A evolução do espaço regional. Das demarcações pombalinas ao Douro pós-filoxèrico. In Pereira, G. (Orgs). História do Douro e do vinho do Porto. Porto: Afrontamento.

Queiroz, M. I. P. (1965). O messianismo no Brasil e no mundo. São Paulo: Dominus Editora.

Revel, J. (1979). Histoire des sciences sociales: les paradigmes des Annales. Annales, E.S.C., $34^{\circ}$ ano, $n^{0} 6$.

Scott, J. C.(1976). The moral economy of the peasant: rebellion and subsistence in southeast Asia. New Havan.

Silva, C. T. (2007). Movimentos Sociais no Douro no período de implantação do liberalismo (1834-1855). Porto: Gehvid.

Snell, K. D. M.(1985). Annals of the labouring poor. Cambridge, 1985.

Taborda, V. (1932). Alto Trás-os-Montes. Estudo geográfico. Coimbra: Imprensa da Universidade.

Thompson, E.(1979). La Economia «Moral» de la multitud en la Inglaterra del siglo XVIII. In Tradición, Revuelta y Consciencia de Clase. Barcelona: Crítica.

Thompson, E. (1995). La Economía Moral Revisada. In Costumbres en Común. Barcelona: Crítica.

Zugasti, J. (s./d.). El bandoleirismo. Estudio Social y Memorias Históricas. Selección y prólogo de E.Inman Fox. Alianza Editorial. 